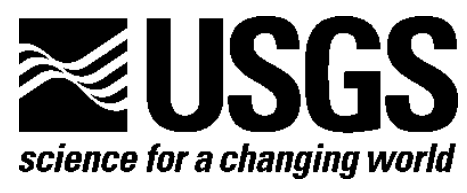

\title{
Status Report for the 3D Elevation Program, 2013-2014
}

By Vicki Lukas, Diane F. Eldridge, Allyson L. Jason, David L. Saghy, Pamela R. Steigerwald, Jason M. Stoker, Larry J. Sugarbaker, and Diana R. Thunen

Open-File Report 2015-1161

U.S. Department of the Interior

U.S. Geological Survey 


\section{U.S. Department of the Interior \\ SALLY JEWELL, Secretary}

\section{U.S. Geological Survey \\ Suzette M. Kimball, Acting Director}

U.S. Geological Survey, Reston, Virginia: 2015

For more information on the USGS—-the Federal source for science about the Earth,

its natural and living resources, natural hazards, and the environment-visit

http://www.usgs.gov or call 1-888-ASK-USGS

For an overview of USGS information products, including maps, imagery, and publications, visit http://www.usgs.gov/pubprod

To order this and other USGS information products, visit http://store.usgs.gov

Any use of trade, firm, or product names is for descriptive purposes only and does not imply endorsement by the U.S. Government.

Although this information product, for the most part, is in the public domain, it also may contain copyrighted materials as noted in the text. Permission to reproduce copyrighted items must be secured from the copyright owner.

Suggested citation:

Lukas, Vicki, Eldridge, D.F., Jason, A.L., Saghy, D.L., Steigerwald, P.R., Stoker, J.M., Sugarbaker, L.J., and Thunen, D.R., 2015, Status report for the 3D Elevation Program, 2013-2014: U.S. Geological Survey Open-File Report 2015-1161, 17 p., http://dx.doi.org/10.3133/ofr20151161. 


\section{Contents}

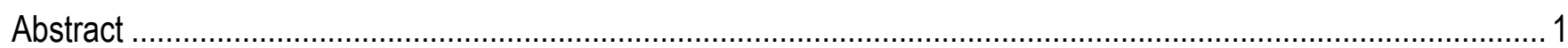

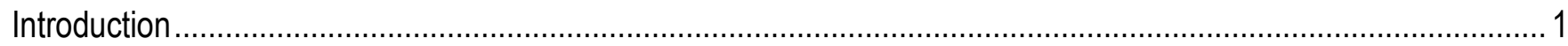

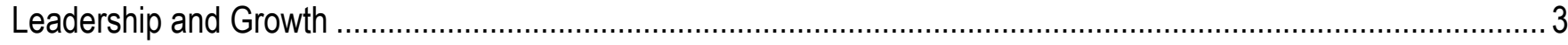

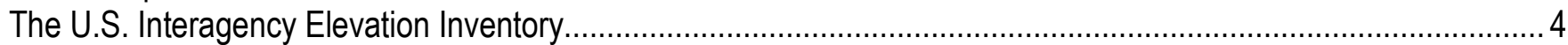

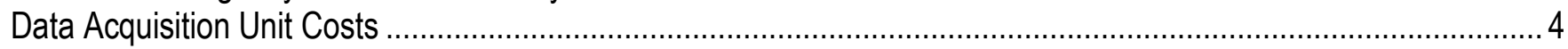

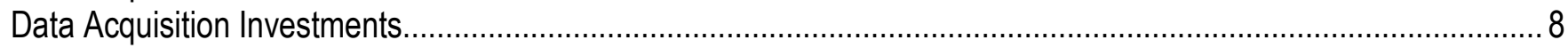

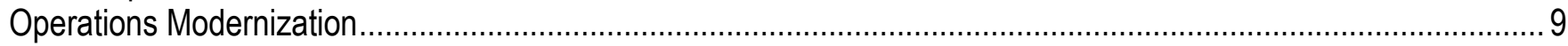

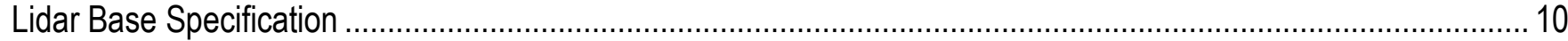

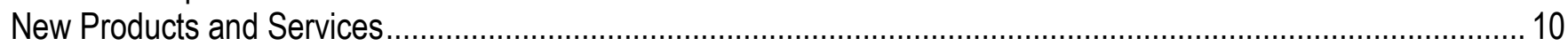

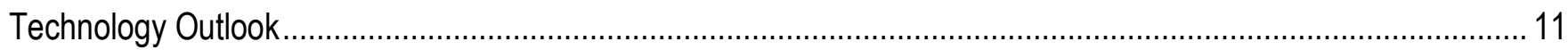

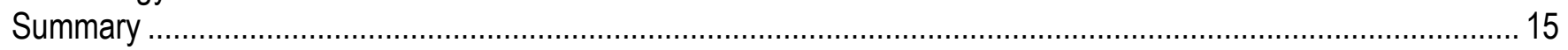

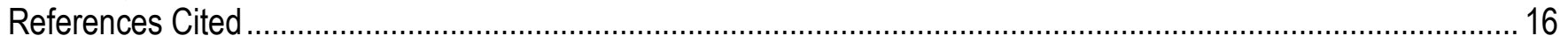

\section{Figures}

1. Elevation data coverage of the United States and U.S. territories derived from light detection and ranging data, and Alaska from interferometric synthetic aperture radar data reported in the 2014 U.S. Interagency Elevation Inventory update .................................................................................

2. Year of elevation data acquisition indicated in the U.S. Interagency Elevation Inventory for quality level 3 or better

3. Acquisition by fiscal year of light detection and ranging data for the United States and U.S. territories showing the percent of lidar coverage of the Nation that was acquired for the first time and additional area where repeat coverage was acquired. Repeat coverage is due primarily to replacing older or less accurate data, or to overlap along the edges of adjacent acquisitions 7

4. Examples of new products and services available through The National Map .......................................... 14

\section{Tables}

1. Data quality levels and related accuracies for the 3D Elevation Program initiative ...................................2

2. Cumulative publicly available 3D Elevation Program quality level 2 and better data coverage....................... 6

3. Comparison of average acquisition costs per square mile by $3 \mathrm{D}$ Elevation Program quality levels................ 8

4. Summary of USGS data acquisition investments in fiscal year 2013 and 2014 ...................................... 9

5. Status and planned release dates for source data from the 3D Elevation Program.................................. 12

6. Status and planned release dates for derived elevation products, including standard digital elevation models, and for services of the 3D Elevation Program 


\section{Conversion Factors}

\begin{tabular}{lcll}
\hline & Multiply & By & \multicolumn{1}{c}{ To obtain } \\
\hline foot $(\mathrm{ft})$ & Length & \\
mile (mi) & 0.3048 & meter $(\mathrm{m})$ \\
\hline \multicolumn{3}{c}{ Area } & \\
\hline square mile $\left(\mathrm{mi}^{2}\right)$ & 1.609 & kilometer $(\mathrm{km})$ \\
\hline
\end{tabular}

The Federal Government's fiscal year (FY) begins October 1 and ends September 30 of the following year. The FY is designated by the calendar year in which it ends; for example, fiscal year 2014 begins on October 1, 2013, and ends on September 30, 2014.

$\begin{array}{ll}\text { Abbreviations } \\ \text { 3D } & \text { three dimensional } \\ \text { 3DEP } & \text { 3D Elevation Program } \\ \text { ASPRS } & \text { American Society for Photogrammetry and Remote Sensing } \\ \text { DEM } & \text { digital elevation model } \\ \text { EROS } & \text { Earth Resources Observation and Science } \\ \text { FAA } & \text { Federal Aviation Administration } \\ \text { FY } & \text { fiscal year } \\ \text { GPSC } & \text { Geospatial Products and Services Contracts } \\ \text { ifsar } & \text { interferometric synthetic aperture radar } \\ \text { lidar } & \text { light detection and ranging } \\ \text { NDEP } & \text { National Digital Elevation Program } \\ \text { NED } & \text { National Elevation Dataset } \\ \text { NEEA } & \text { National Enhanced Elevation Assessment } \\ \text { NGAC } & \text { National Geospatial Advisory Committee } \\ \text { NGP } & \text { National Geospatial Program } \\ \text { NGTOC } & \text { National Geospatial Technical Operations Center } \\ \text { OMB } & \text { Office of Management and Budget } \\ \text { ORI } & \text { orthorectified radar intensity } \\ \text { QA/QC } & \text { quality assurance/quality control } \\ \text { QL } & \text { quality level } \\ \text { RMSEz } & \text { root mean square error in the z (elevation) dimension } \\ \text { UAV } & \text { unmanned aerial vehicle } \\ \text { USGS } & \text { U.S. Geological Survey } \\ \text { USIEI } & \text { U.S. Interagency Elevation Inventory } \\ & \end{array}$




\title{
Status Report for the 3D Elevation Program, 2013-2014
}

\author{
By Vicki Lukas, Diane F. Eldridge, Allyson L. Jason, David L. Saghy, Pamela R. Steigerwald, Jason M. Stoker,
} Larry J. Sugarbaker, and Diana R. Thunen

\begin{abstract}
The 3D Elevation Program (3DEP) goal is to acquire, manage, and distribute enhanced threedimensional elevation data for the Nation and U.S. territories by 2023 . This status report covers implementation activities during 2013-2014 to include meeting funding objectives, developing a management structure, modernizing systems, and collecting and producing initial 3DEP data and products. The Nation will not have complete coverage of 3DEP quality data until 2023 assuming that sufficient funding is available. In spite of the overall condition of government budgets, the 3DEP initiative has gained widespread support and had incremental budget success to include supplemental funding resulting from natural disasters. The 3DEP Executive Forum and a wide range of professional organizations are actively working to maintain support for the program. The systems that have been developed to support increasing acquisition and processing levels are largely in place. The first 3DEP quality datasets were released to the public in late 2014. In addition, light detection and ranging (lidar), interferometric synthetic aperture radar (ifsar), and digital elevation models (DEMs) acquired before 2014 are all supported within the new infrastructure and available for download. Research is ongoing to expand the suite of products and services, and to increase overall throughput and data management efficiency. Emerging technologies may result in lower acquisition costs in the future. Elevation data acquired by 3DEP partnerships will be available through The National Map representing one of the largest and most comprehensive databases publicly available for the United States.
\end{abstract}

\section{Introduction}

To respond to growing needs for high-quality topographic data and for a wide range of other three-dimensional (3D) representations of the Nation's natural and constructed features, the U.S. Geological Survey (USGS) National Geospatial Program (NGP) is developing the 3D Elevation Program (3DEP). The primary goal of 3DEP is to systematically collect 3D elevation data during an 8year period from 2016 to 2023 in the form of light detection and ranging (lidar) data over the conterminous United States, Hawaii, and the U.S. territories. Interferometric synthetic aperture radar (ifsar) data will be acquired for Alaska, where cloud cover and remote locations preclude the use of lidar in much of the State. The 3DEP initiative is based on the results of the National Enhanced Elevation Assessment (NEEA; U.S. Geological Survey, The National Map, 2014a; Snyder and others, 2014) that documented more than 600 business uses of lidar across 34 Federal agencies, all 50 States, selected local government and tribal offices, and private and nonprofit organizations. Based on the benefit-cost analysis in the NEEA, a fully funded and implemented 3DEP would provide more than $\$ 690$ million annually in new benefits to government entities, the private sector, and citizens. The 3DEP presents a unique opportunity for collaboration among all levels of government, to leverage the services and expertise of private sector mapping firms that acquire the data, and to create jobs now and in the future. 
When 3D elevation data are available to everyone, innovations are possible in flood risk management, resource management, alternative energy, agriculture, and a host of other industries for years to come.

To achieve the level of benefits estimated in the NEEA, the 3DEP initiative must improve the quality level at which data are acquired nationally (table 1). The minimum quality levels (QLs) for data acquired through the 3DEP initiative are QL2 lidar data for the lower 48 States, Hawaii, and the U.S. territories; and QL5 ifsar data for Alaska. The elevation data collection properties for the 3DEP initiative approximate those used in the NEEA study (Dewberry, 2012), which categorized elevation data source in five QLs. The data sources have been adjusted slightly in table 1 to conform to American Society for Photogrammetry and Remote Sensing standards (American Society for Photogrammetry and Remote Sensing, 2014). The QL3 approximates the base-level specification for lidar data collected by the USGS through fiscal year 2013 (Heidemann, 2012). The current base specification, version 1.2, reflects QL2 as the base level in accordance with the 3DEP initiative recommendation. The QL nomenclature has changed from its first use in the NEEA study and its subsequent use in the USGS acquisition specification.

Table 1. Data quality levels and related accuracies for the 3D Elevation Program initiative.

$\left[\mathrm{RMSE}_{\mathrm{z}}\right.$, root mean square error in the $\mathrm{z}$ (elevation) dimension; DEM, digital elevation model; QL, quality level; lidar, light detection and ranging; n/a, not applicable; ifsar, interferometric synthetic aperture radar]

\begin{tabular}{|c|c|c|c|c|c|}
\hline $\begin{array}{c}\text { Quality } \\
\text { level }\end{array}$ & $\begin{array}{c}\text { Data } \\
\text { source }\end{array}$ & $\begin{array}{l}\text { Vertical error } \\
\left(\text { RMSE }_{z}\right) \\
\text { (centimeters) }\end{array}$ & $\begin{array}{l}\text { Nominal pulse } \\
\text { spacing }{ }^{1} \\
\text { (meters) }\end{array}$ & $\begin{array}{c}\text { Nominal pulse } \\
\text { density }{ }^{2} \\
\text { (points per square } \\
\text { meter) }\end{array}$ & $\begin{array}{c}\text { DEM } \\
\text { cell size } \\
\text { (meters) }\end{array}$ \\
\hline QL1 & Lidar & 10 & 0.35 & 8 & 0.5 \\
\hline QL2 & Lidar & 10 & 0.7 & 2 & 1 \\
\hline QL3 & Lidar & 20 & 1.4 & 0.5 & $2^{3}$ \\
\hline QL4 & Aerial imagery & 139 & $\mathrm{n} / \mathrm{a}$ & $\mathrm{n} / \mathrm{a}$ & 5 \\
\hline QL5 & Ifsar & 185 & $\mathrm{n} / \mathrm{a}$ & $\mathrm{n} / \mathrm{a}$ & 5 \\
\hline
\end{tabular}

\footnotetext{
${ }^{1}$ Nominal pulse spacing is the typical or average lateral distance between irregularly spaced first-return points in a lidar dataset, most simply calculated and expressed as the square root of the average area per elevation point: $N P S=\frac{1}{\sqrt{N P D}}$ ${ }^{2}$ Nominal pulse density estimates the number of first-return lidar points per square meter: $N P D=\frac{1}{N P S^{2}}$

${ }^{3}$ Although many historical DEMs created from QL3 data have had a resolution (cell size) of 3 meters to match the 1/9 arcsecond National Elevation Dataset (NED), the QL3 data will support the production of a 2-meter DEM.
}

This report to 3DEP collaborators and stakeholders summarizes the program achievements for 2013 and 2014. It also reflects the commitment by the USGS to coordinate, communicate, and improve the public availability of terrestrial elevation data as part of the USGS colead agency responsibility as designated by the Office of Management and Budget (OMB) through OMB Circular A-16 (Office of Management and Budget, 2002). 


\section{Leadership and Growth}

Highlights of 2013-14 include the following activities:

- The 3DEP Executive Forum.-The 3DEP Executive Forum was established in 2013 to facilitate executive-level dialog and collaboration on strategies to implement and sustain 3DEP and other elevation datasets of national significance in order to fulfill OMB Circular A-16 theme coordination requirements for the benefit of Federal stakeholders and the broader community. Members are executive-level Federal representatives of the National Digital Elevation Program (NDEP) Committee and other agencies with significant potential benefits from a national elevation program. The 3DEP Executive Forum meets quarterly and addresses ongoing topics such as strategies to advance emerging lidar technology, legislation related to 3D elevation and 3DEP, and Federal data acquisition partnerships.

- The 3D Elevation Program Initiative-A Call for Action.-Sugarbaker and others (2014) provide a detailed summary of the $3 \mathrm{DEP}$ plan and direction. The report was developed with extensive input and review by stakeholders including the 3DEP Executive Forum, the NDEP Committee, and the National Geospatial Advisory Committee (NGAC) under the Federal Geographic Data Committee.

- Endorsements and other support.-The 3DEP initiative was endorsed or received letters of budget support from the American Society for Photogrammetry and Remote Sensing (ASPRS), Association of American State Geologists (AASG), Association of State Floodplain Managers (ASFPM), Coalition of Geospatial Organizations (COGO), the Management Association for Private Photogrammetric Surveyors (MAPPS), National Geospatial Advisory Committee, (NGAC), National Society of Professional Surveyors (NSPS), and the National States Geographic Information Council (NSGIC).

- National Academy of Public Administration report.-The November 2013 National Academy of Public Administration (2013, p. 11) report included the following recommendation: "The Office of Management and Budget should use the 3DEP implementation plan for nationwide elevation data collection to guide the development of the President's annual budget request."

- Legislative hearing.-The 3DEP initiative was recognized as an opportunity for strengthening geospatial coordination as part of the hearing on H.R. 1604 and H.R. 916 (http://docs.house.gov/Committee/Calendar/ByEvent.aspx?EventID=101580) by the House Committee on Natural Resources, Subcommittee on Energy and Mineral Resources. H.R. 1604, the "Map It Once, Use It Many Times Act," proposed to establish the National Geospatial Technology Administration within the USGS to enhance the use of geospatial data, products, technology, and services to increase the economy and efficiency of Federal geospatial activities. H.R. 916, the Federal Land Asset Inventory Reform Act of 2013, was intended to improve Federal land management, resource conservation, environmental protection, and the use of Federal real property by requiring the Secretary of the Interior to develop a multipurpose cadastre of Federal real property.

- Congressional briefings.- On July 25, 2014, the House and Senate were briefed on "Safer Communities, Stronger Economies - in 3D." Speakers from the State of North Carolina, Federal Emergency Management Agency, and USGS presented 3DEP applications that help communities cope with natural hazards, support infrastructure, and strengthen environmental decision-making (U.S. Geological Survey, Congressional Briefing Series, 2014). 
- The White House fact sheet.-On July 16, 2014, the White House announced that the USGS and other Federal agencies were launching a 3DEP partnership designed to bring Federal agencies, academia, corporate entities, states, tribes, and communities together to acquire advanced 3D mapping data of the United States (White House, The, 2014a). These data and related tools will support many applications, including flood risk management, water resource planning, mitigation of coastal erosion and storm surge effects, and the identification of landslide hazards as an essential component of supporting action on climate resilience. Plans to produce 3D data and maps were highlighted in President Obama's press release (White House, The, 2014b).

- Budget.- The 3DEP initiative was identified in the fiscal year (FY) 2014 President's budget (U.S. Geological Survey, 2013) with a funding increase to the USGS of \$9 million plus \$1 million specifically for Alaska ifsar data. The enacted budget did not include the increase for 3DEP, but did include $\$ 760,000$ for Alaska elevation data that supports 3DEP goals. The FY 2015 President's budget (U.S. Geological Survey, 2014) included a \$5 million increase for 3DEP, $\$ 760,000$ for Alaska mapping, and \$800,000 for lidar for the Puget Sound and Columbia River ecosystems. The enacted budget included the $\$ 5$ million increase for 3DEP and \$236,000 for Alaska mapping.

\section{The U.S. Interagency Elevation Inventory}

The USGS and the National Oceanic and Atmospheric Administration annually collect information about publicly available lidar data (including ifsar data in Alaska) and maintain the U.S. Interagency Elevation Inventory (USIEI) Web site where this information can be viewed (see http://coast.noaa.gov/inventory/). An update to the USIEI data through FY 2014 (fig. 1) indicates the cumulative data coverage shown in table 2 (includes all QLs, and plans and acquisitions identified through October 2014).

The annual data acquisition levels increased in 2007, 2009, 2010 and 2012 (figs. 2-3). The collection rates were aided by the 2009 American Recovery and Reinvestment Act, and a significant number of statewide and regional data collections in the Midwest and the State of Alaska. Collection rates fell in 2013 and remained at a similar level in 2014 (fig. 3) because of decreases in Federal and State data acquisition funding. To achieve the 3DEP 8-year coverage goal, 12 percent of the Nation needs to be acquired each year.

\section{Data Acquisition Unit Costs}

For FYs 2012-14, average data acquisition costs were calculated from the annual records of the Geospatial Products and Services Contracts (GPSC) and from other partnership contracts. A comparison of costs for data acquisition by quality level reveals that the annual number and average size of projects (table 3) have been highly variable, and thus cost trends cannot be discerned. Across all projects there has been a significant shift away from QL3 projects in favor of higher quality QL1 and QL2 data collections. 


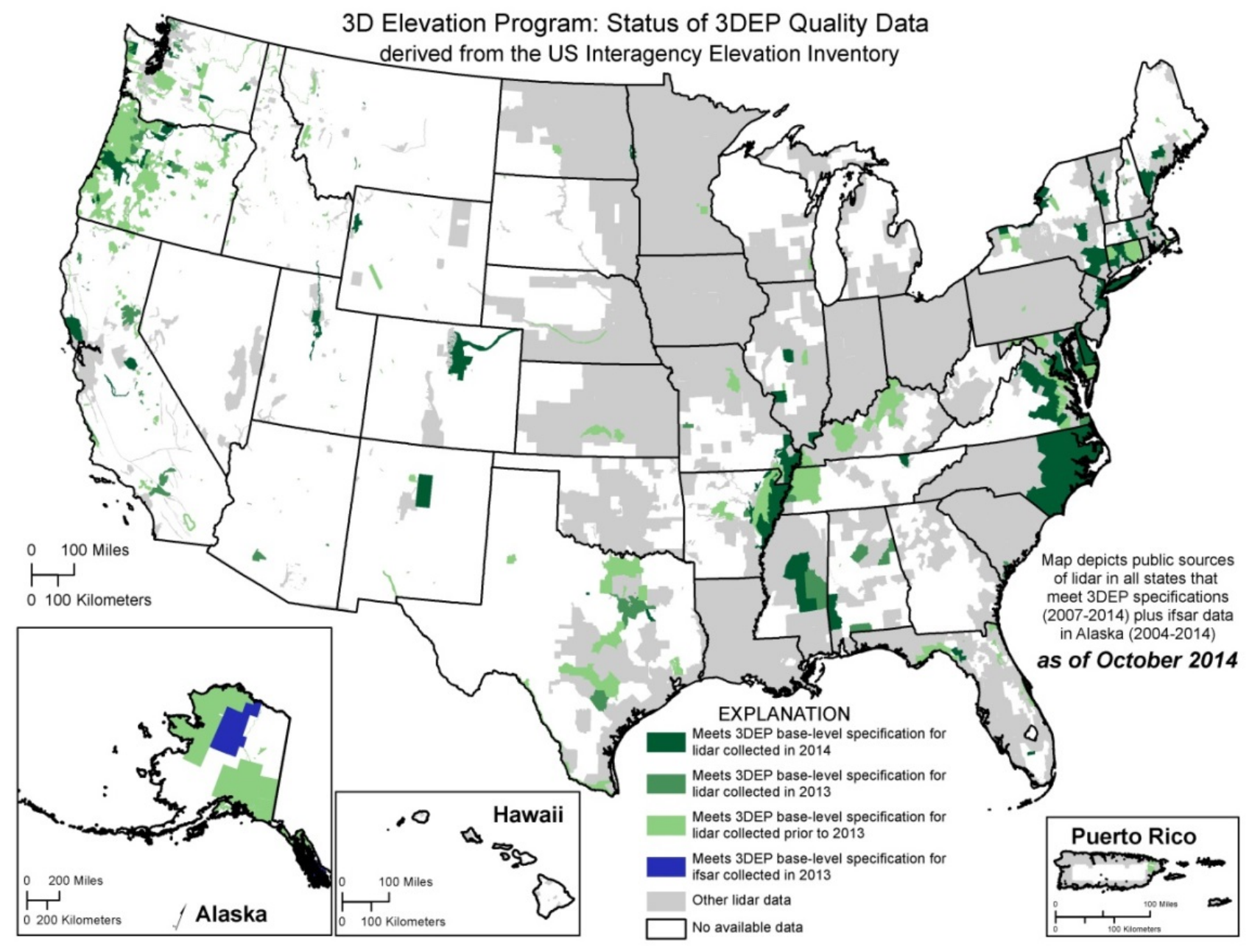

Figure 1. Elevation data coverage of the United States and U.S. territories derived from light detection and ranging (lidar) data, and Alaska from interferometric synthetic aperture radar (ifsar) data reported in the 2014 U.S. Interagency Elevation Inventory update. 
Table 2. Cumulative publicly available 3D Elevation Program quality level 2 and better data coverage.

[Data compiled from the U.S. Interagency Elevation Inventory as of October 2014. lidar, light detection and ranging; 3DEP, 3D Elevation Program; QL, quality level; ifsar, interferometric synthetic aperture radar]

\begin{tabular}{lcc}
\hline & Fiscal year 20131 & Fiscal year 2014,2 \\
\hline $\begin{array}{l}\text { Total area of the lower 48 States, Hawaii, and the U.S. territories that has } \\
\text { lidar coverage that meets the 3DEP specification }\end{array}$ for QL2 or better & 4 percent & 6.8 percent \\
$\begin{array}{l}\text { Total area of Alaska that has ifsar coverage that meets the 3DEP } \\
\text { specification for the State }\end{array}$ & 50.2 percent $^{4}$ & 50.2 percent $^{4}$ \\
\hline
\end{tabular}

${ }^{1}$ The U.S. Interagency Elevation Inventory (USIEI) tracks data based on the year the data were acquired by the sensor, not the year the data were purchased.

${ }^{2}$ The fiscal year is estimated. Because of the nature of lidar (ifsar) data acquisition, the USIEI tracks some types of planned data acquisitions that have the potential to not be acquired in the reported fiscal year. These projects are included in this table, but may be revised in the subsequent year's inventory update.

${ }^{3}$ Meets 3DEP specification defined as QL2 or better data and 8 years or newer in the lower 48 States, Hawaii, and the U.S. territories; and QL5 or better in Alaska.

${ }^{4}$ Fiscal year 2014 data acquisitions funds were used to process about 80,000 square miles of data that had been collected in previous years.

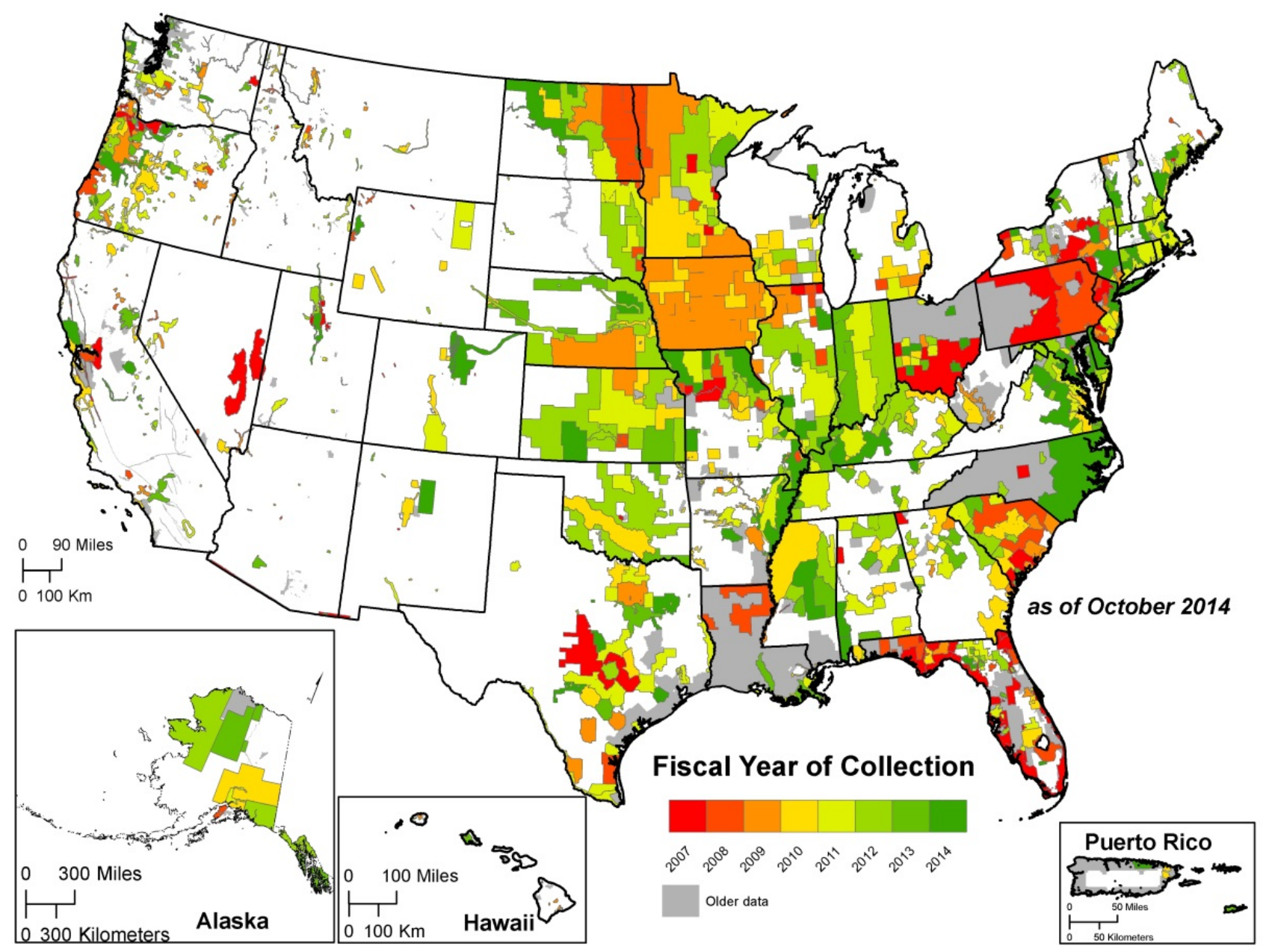

Figure 2. Year of elevation data acquisition (fiscal years 2007-14) indicated in the U.S. Interagency Elevation Inventory for quality level 3 or better. 


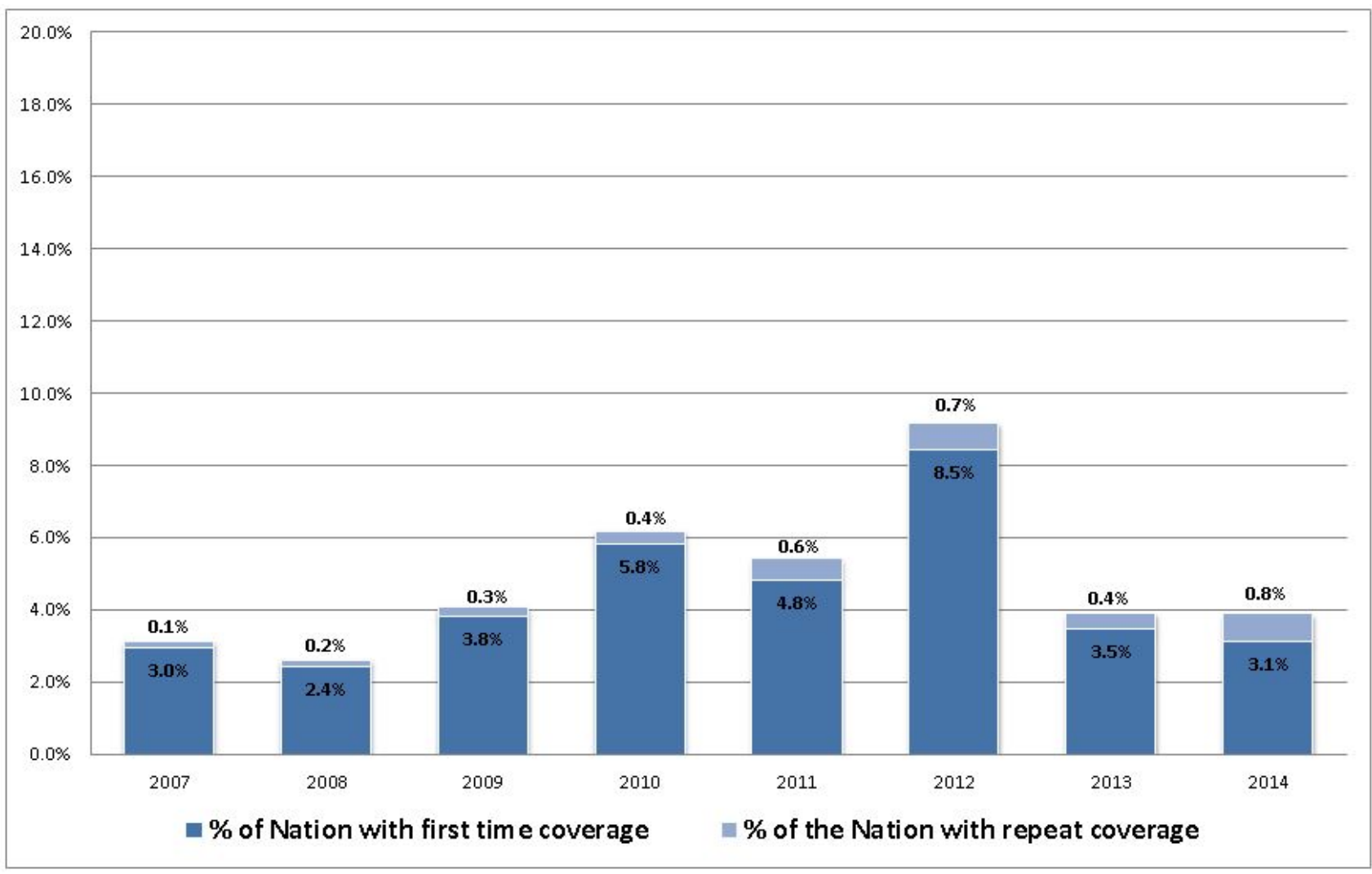

Figure 3. Acquisition by fiscal year of light detection and ranging data (lidar; all quality levels) for the United States and U.S. territories showing the percent of lidar coverage of the Nation that was acquired for the first time and additional area where repeat coverage was acquired. Repeat coverage is due primarily to replacing older or less accurate data, or to overlap along the edges of adjacent acquisitions. 
Table 3. Comparison of average acquisition costs per square mile by 3D Elevation Program quality levels.

[2012 average cost per square mile (number of projects/average size of project in square miles); QL, quality level; lidar, light detection and ranging; ifsar, interferometric synthetic aperture radar; N/A, not applicable]

\begin{tabular}{llll}
\hline \multicolumn{1}{c}{ Quality level1 } & \multicolumn{1}{c}{$\begin{array}{c}\text { 2012 average } \\
\text { cost per square mile }\end{array}$} & $\begin{array}{c}\text { 2013 average } \\
\text { cost per square } \text { mile }^{2}\end{array}$ & $\begin{array}{c}\text { 2014 average } \\
\text { cost per square mile }\end{array}$ \\
\hline QL1 lidar (lower 48 States) & $\$ 842(1 / 2,021)$ & $\$ 627(6 / 934)$ & $\$ 821(7 / 1,009)$ \\
QL2 lidar (lower 48 States) & $\$ 457(3 / 648)$ & $\$ 348(20 / 1,665)$ & $\$ 343(23 / 2,504)$ \\
QL3 lidar (lower 48 States) & $\$ 275(28 / 2,183)$ & $\$ 172(9 / 2,632)$ & $\$ 266(4 / 6,225)$ \\
QL5 ifsar (Alaska) & $\$ 95$ & $\$ 100$ & N/A \\
\hline
\end{tabular}

${ }^{1}$ For definitions of quality levels, refer to the "Introduction" section.

${ }^{2}$ Average costs include collection, quality assurance/quality control, and management. Collection cost is about 80 percent of total acquisition cost shown in this table. Numbers within parentheses next to lidar cost information are total number of projects flown and average project size in square miles for Geospatial Products and Services Contracts (GPSC) and partner projects. Costs for the collection of data in Hawaii, Puerto Rico, and the U.S. Trust Territories are highly variable because of the high costs of aircraft mobilization, weather, and other factors related to operating in remote locations. The costs identified can be used as a baseline for developing project estimates; however, care should be exercised using the average cost figures for data-collection cost estimates in these locations.

The cost associated with ifsar data collection in Alaska increased slightly in 2013. The average cost for ifsar collection in Alaska during 2013 was about $\$ 100$ per square mile $\left(\mathrm{mi}^{2}\right)$. The 2013 cost increase can be attributed to data-processing, difficult terrain and heavy forest, fuel, and nonstandard coastal flight lines. Costs may continue to change as more is learned about data acquisition in the State's challenging terrains.

The projected acquisition cost [including collection, quality assurance/quality control (QA/QC), management] for 3DEP data is $\$ 334 / \mathrm{mi}^{2}$ for QL2 projects averaging 5,000 $\mathrm{mi}^{2}$. In 2014, the average cost of QL2 projects was $\$ 343 / \mathrm{mi}^{2}$, and the average project size was 2,504 $\mathrm{mi}^{2}$. For lidar and ifsar data collection, the costs through 2014 were roughly compatible with those used to calculate the overall cost of acquiring National 3DEP coverage. Costs will continue to be analyzed on an annual basis to assess any needed changes in the overall 3DEP required funding profile.

\section{Data Acquisition Investments}

Initial steps were taken in FY 2013 to shift USGS data acquisition investments to higher quality (QL2) data as outlined in the 3DEP plan. The USGS invested \$4.04 million in FY 2013 and \$7.31 million in FY 2014 to acquire combined QL1 and QL2 lidar (table 4). Additionally, the USGS invested \$560,000 in FY 2013 and \$700,000 in FY 2014 for QL3 lidar data. Most of the QL3 projects completed in FY 2013 and FY 2014 were part of multiyear partnership activities that were commitments from prior years. The USGS data acquisition investments included NGP funds, other program funds, and Hurricane Sandy supplemental funds. 
Table 4. Summary of USGS data acquisition investments in fiscal year 2013 and 2014.

[Note that cooperator funds represent the value as identified in cooperative agreements. Actual cooperator investments, which would include administrative and QA/QC costs are likely higher. In addition, some data were contributed to USGS and are being made available for download. These contributed datasets are not included in the summary information below. USGS, U.S. Geological Survey; lidar, light detection and ranging; QL, quality level; ifsar, interferometric synthetic aperture radar]

\begin{tabular}{|c|c|c|c|c|c|c|c|c|}
\hline & \multicolumn{4}{|c|}{ Fiscal year 2013} & \multicolumn{4}{|c|}{ Fiscal year 2014} \\
\hline & $\begin{array}{c}\text { Square } \\
\text { miles } \\
\text { acquired }\end{array}$ & $\begin{array}{c}\text { USGS } \\
\text { funds (all } \\
\text { sources) }\end{array}$ & $\begin{array}{l}\text { Cooperator } \\
\text { funds }\end{array}$ & Total funds & $\begin{array}{l}\text { Square } \\
\text { miles } \\
\text { acquired }\end{array}$ & $\begin{array}{l}\text { USGS } \\
\text { funds (all } \\
\text { sources) }\end{array}$ & $\begin{array}{l}\text { Cooperator } \\
\text { funds }\end{array}$ & Total funds \\
\hline $\begin{array}{l}\text { Lidar } \\
\text { QL1-2 }\end{array}$ & 48,000 & $\$ 4,040,000$ & $\$ 9,330,000$ & $\$ 13,370,000$ & 80,000 & $\$ 7,310,000$ & $\$ 15,750,000$ & $\$ 23,060,000$ \\
\hline $\begin{array}{l}\text { Lidar QL3 } \\
\text { Ifsar }\end{array}$ & 24,000 & $\$ 560,000$ & $\$ 2,800,000$ & $\$ 3,360,000$ & 25,000 & $\$ 700,000$ & $\$ 4,780,000$ & $\$ 5,480,000$ \\
\hline (Alaska) & 69,000 & $\$ 3,540,000$ & $\$ 3,240,000$ & $\$ 6,780,000$ & 80,000 & $\$ 2,840,000$ & $\$ 4,070,000$ & $\$ 6,910,000$ \\
\hline
\end{tabular}

In order to achieve national coverage on an aggressive 8-year cycle, the 3DEP initiative must build on existing relations to establish a systematic and more unified process for data acquisition partnerships. In coordination with the NDEP, the USGS is collaborating with Federal, State, and other partners to define the process with initial implementation in FY 2015; and continued refinement in subsequent years in accordance with increased stakeholder engagement, available funding, and new technologies. On July 18, 2014, the USGS issued a Broad Agency Announcement (BAA) that provided detailed information on this initial partnership opportunity with the USGS 3DEP program. To ensure maximum awareness of the opportunity throughout the stakeholder community, the BAA was posted on Fed Biz Opps and Grants.gov (Reference number: G14PS00574, see http://www.grants.gov/web/grants/ search-grants.html?keywords=G14PS00574). The preferred method of data acquisition for 3DEP is through the USGS GPSC. Firms under contract with the USGS as part of the GPSC have been selected based on their qualifications and performance in providing professional services. To ensure data quality and efficient development of standard products and services, the USGS encourages partners to use the GPSC when possible and practical; however, the BAA allows offerors to propose acquisition projects either through the GPSC or request 3DEP funds toward acquisition projects using the partner's contracting vehicle. For continued access to reference and communication materials associated with current and future BAAs, U.S. Geological Survey, The National Map (2015) has established a reference site as part of the 3DEP web presence. To support the increased data acquisition and processing required to meet 3DEP coverage goals, the GPSC will be re-competed in FY 2015 to establish a new contract for 5 years and increase the delegated procurement authority from $\$ 250$ million to $\$ 750$ million. The increased procurement authority will ensure that there is contracting capacity to handle any increased appropriations for 3DEP and other geospatial needs.

\section{Operations Modernization}

Production capability for updating and distributing standard digital elevation models (DEMs) [previously referred to as the National Elevation Dataset (NED)] was completely re-engineered and operationalized within the National Geospatial Technical Operations Center (NGTOC) by April 2014. Significant improvements in process automation, as well as modernized production and distribution infrastructure, provide consistent product quality at the increased throughput rates required for the high volume of 3DEP data. In addition to standard DEMs, the production system simultaneously prepares 
and stages lidar point cloud datasets and original (source) resolution DEMs for distribution. An elevation point query service that retrieves elevations for user-input coordinates is also available. About 45 terabytes of standard 3DEP DEMs and lidar point cloud datasets were downloadable through The National Map by October 2014. Development is on track for production and distribution of ifsar digital surface models and orthorectified radar intensity (ORI) images beginning January 2015.

\section{Lidar Base Specification}

The success of the 3DEP initiative as a collaborative effort depends on community acceptance and implementation of a data acquisition specification. The 3DEP data specification has continued to evolve with the following recent (2014) and anticipated improvements:

- Version 1.2 (Heidemann, 2014), published November 12, 2014, augments the existing version 1.0 (Heidemann, 2012) to define specifications for QL2 and QL1 data, and address the transition of the point cloud data file format specification published by ASPRS from LAS file format 1.2/1.3 to LAS file format 1.4 (November 2011) (American Society for Photogrammetry and Remote Sensing, 2012).

- Version 2.0, planned for publication in 2016, is being developed to address the collection and delivery of hydrographic data to ensure interoperability across data collections, allow seamless transition of hydrographic data into the National Hydrography Dataset, and enforce hydrography consistency with lidar point clouds. The integration of elevation and hydrographic data at the collection stage would enable more efficient creation and provision of products for use in a wide range of applications.

- Emerging new lidar technologies (such as Geiger and photon-counting lidar) offer potential advantages to 3DEP in cost, time, and data content. They also present a substantial change in data structure and handling. The lidar base specification, as well as other industry standards such as the LAS file format, will include changes to accommodate these instruments as they become commercially usable. Working with the developers of these systems, the ASPRS, and other standards organizations will be key to ensuring these instruments and data can be fully used by 3DEP and its customers.

\section{New Products and Services}

New products and services outlined in tables 5 and 6 are scheduled to be in place in 2015 (fig. 4) including 1-meter DEMs, 5-meter DEMs in Alaska, lidar point cloud source datasets and ifsar source digital surface models and ORI data in Alaska; all above information is available on The National Map data portal (U.S. Geological Survey, The National Map, 2015b) and the Geospatial Platform (see https://www.geoplatform.gov/). Along with the introduction of the new products, the NED name will be phased out, and the new 3DEP brand will be implemented on the Web site and other print media. The elevation data will continue to be updated and provided at the resolutions of 1/3, 1, and 2 arc-seconds under the 3DEP brand; and the 1/9 arc-second DEMs will not be updated, but will be available as a legacy product under 3DEP. Lidar specifications for data collection, classified point cloud, and source DEMs acquired between 2012 and 2014 are in Heidemann (2012).

Special request products are available by contacting either the Earth Resources Observation and Science (EROS) Center or NGTOC. The EROS Center provides source data through the Earth Explorer application. The NGTOC provides source data through The National Map delivery services. Earth Explorer and The National Map products and services are available online. 


\section{Technology Outlook}

Although advancements in airborne systems have been incremental, some have had significant effects on the industry, and the emerging technologies listed below may result in lower data collection costs within the next 5 years:

- The development of higher spatial resolution, green-wavelength airborne lidar systems is enabling seamless topo bathymetric data collection along land-water interfaces in coastal and riverine environments. Airborne lidar bathymetry systems are beginning to use lower powered sensors with tighter beam divergence enabling smaller, higher flying platforms.

- The introduction of unmanned aerial vehicles (UAVs), or drones, for lidar data-collection services could have a significant industry effect that further reduces the costs of data collection. The Federal Aviation Administration (FAA) Modernization and Reform Act of 2012 requires the FAA to implement rules and procedures for licensing drone use by government agencies, commercial entities, hobbyists, and others. The FAA is currently developing the rules and procedures; however, it is not known how soon UAVs will be available to geospatial data service providers.

- Photon-counting and Geiger mode lidar systems may improve upon conventional lidar (see paragraph below).

- Declines in computer technology costs for storage and processing should lower the costs of managing and archiving large lidar, ifsar, and elevation product datasets. In addition, cloud services may lower costs through the use of shared technology services available from commercial information technology service providers.

- The emerging Geospatial Platform may allow the USGS to provide online services and provide a lower cost solution for customers needing access to the elevation data. 


\section{Table 5. Status and planned release dates for source data from the 3D Elevation Program.}

[The initial source data availability will be limited to newly acquired project datasets. QL, quality level; lidar, light detection and ranging; NGTOC, National Geospatial Technical Operations Center; ifsar, interferometric synthetic aperture radar; DEM, digital elevation model; TBD, to be determined]

\begin{tabular}{|c|c|c|c|c|}
\hline Source data & $\begin{array}{l}\text { Planned coverage on } \\
\text { release date }\end{array}$ & Sources (QL) & $\begin{array}{l}\text { Planned product } \\
\text { or service }\end{array}$ & $\begin{array}{l}\text { Planned availability } \\
\text { (release date }{ }^{1} \text { ) }\end{array}$ \\
\hline $\begin{array}{l}\text { Lidar full point } \\
\text { cloud- } \\
\text { Unclassified }\end{array}$ & $\begin{array}{l}\text { Partial coverage of the } \\
\text { United States }\end{array}$ & $\begin{array}{l}\text { Lidar (QL1, } \\
\quad \text { QL2, QL3) }\end{array}$ & $\begin{array}{l}\text { Project areas by special } \\
\text { request }\end{array}$ & NGTOC 2014. \\
\hline $\begin{array}{l}\text { Lidar full point } \\
\text { cloud-Classified }\end{array}$ & $\begin{array}{l}\text { Partial coverage of the } \\
\text { United States }\end{array}$ & $\begin{array}{l}\text { Lidar (QL1, } \\
\text { QL2, QL3) }\end{array}$ & $\begin{array}{l}\text { Project tiles by } \\
\text { download }\end{array}$ & $\begin{array}{l}\text { Earth Explorer and The National } \\
\text { Map }^{2} \text {, and GeoPlatform } \\
2\end{array}$ \\
\hline $\begin{array}{l}\text { Ifsar digital surface } \\
\text { model }\end{array}$ & $\begin{array}{l}\text { Partial coverage of } \\
\text { Alaska }\end{array}$ & Ifsar (QL5) & $\begin{array}{l}\text { Project tiles by } \\
\text { download }\end{array}$ & $\begin{array}{l}\text { Earth Explorer and The National } \\
\text { Map }^{2} 2014 \text {. }\end{array}$ \\
\hline $\begin{array}{l}\text { Orthorectified ifsar } \\
\text { intensity image }\end{array}$ & $\begin{array}{l}\text { Partial coverage of } \\
\text { Alaska }\end{array}$ & Ifsar (QL5) & $\begin{array}{l}\text { Project tiles by } \\
\text { download }\end{array}$ & $\begin{array}{l}\text { Earth Explorer and The National } \\
\operatorname{Map}^{2} 2014 \text {. }\end{array}$ \\
\hline $\begin{array}{l}\text { Source resolution } \\
\text { DEM }\end{array}$ & $\begin{array}{l}\text { Partial coverage } \\
\text { of the United States } \\
\text { and some U.S. } \\
\text { territories }\end{array}$ & Lidar, ifsar & $\begin{array}{l}\text { Project tiles by } \\
\text { download }\end{array}$ & $\begin{array}{l}\text { The National } \mathrm{Map}^{2} \text {, and } \\
\text { GeoPlatform } \\
\text { data and } 2014 \text { for new for pre } 2014 \\
\text { data). }\end{array}$ \\
\hline
\end{tabular}

${ }^{1}$ All release dates are preliminary.

${ }^{2}$ U.S. Geological Survey, The National Map (2014b).

${ }^{3}$ Geospatial Platform (2014a, 2014b). 
Table 6. Status and planned release dates for derived elevation products, including standard digital elevation models (DEMs), and for services of the 3D Elevation Program.

[For the initial standard products, geographic coverage will be limited for many products because of limited availability of source data. DEM, digital elevation model; lidar, light detection and ranging; TBD, to be determined; AK, Alaska; ifsar, interferometric synthetic aperture radar; CONUS, conterminous United States; HI, Hawaii]

\begin{tabular}{|c|c|c|c|c|}
\hline Product & $\begin{array}{l}\text { Planned coverage } \\
\text { on release date }\end{array}$ & Sources & $\begin{array}{l}\text { Planned product } \\
\text { or service }\end{array}$ & $\begin{array}{l}\text { Planned availability } \\
\text { (release date }{ }^{1} \text { ) }\end{array}$ \\
\hline 1-meter DEM & $\begin{array}{l}\text { Partial coverage of the } \\
\text { United States and } \\
\text { some U.S. territories }\end{array}$ & Lidar & $\begin{array}{l}\text { Tiles (TBD) by } \\
\text { download }\end{array}$ & $\begin{array}{c}\text { The National Map }{ }^{2} \text { and } \\
\text { GeoPlatform } \\
2014 .\end{array}$ \\
\hline 5-meter DEM & Partial coverage of $\mathrm{AK}$ & Ifsar & $\begin{array}{l}\text { 1-degree } \times 1 \text {-degree block } \\
\text { by download }\end{array}$ & $\begin{array}{l}\text { The National Map }{ }^{2}, \\
\text { GeoPlatform }{ }^{3} \text {, and } \\
\text { Earth Explorer } 2014 .\end{array}$ \\
\hline $\begin{array}{l}\text { 1/9 arc-second } \\
\text { DEM-Legacy }\end{array}$ & $\begin{array}{l}\text { Partial coverage of the } \\
\text { United States and } \\
\text { some U.S. territories }\end{array}$ & $\begin{array}{l}\text { Lidar, ifsar, } \\
\text { photogrammetry }\end{array}$ & $\begin{array}{l}15 \text {-minute } \times 15 \text {-minute } \\
\text { block by download }\end{array}$ & $\begin{array}{c}\text { The National Map }{ }^{2} \text { and } \\
\text { GeoPlatform } \\
2014 .\end{array}$ \\
\hline 1/3 arc-second DEM & $\begin{array}{l}\text { CONUS, HI, some U.S. } \\
\text { territories, and parts } \\
\text { of AK }\end{array}$ & $\begin{array}{l}\text { Lidar, ifsar, } \\
\text { photogrammetry }\end{array}$ & $\begin{array}{l}\text { 1-degree } \times 1 \text {-degree block } \\
\text { by download }\end{array}$ & $\begin{array}{c}\text { The National } \mathrm{Map}^{2} \text { and } \\
\text { GeoPlatform } \\
2014 .\end{array}$ \\
\hline 1 arc-second DEM & $\begin{array}{l}\text { CONUS, HI, AK, and } \\
\text { U.S. territories }\end{array}$ & $\begin{array}{l}\text { Lidar, ifsar, } \\
\text { photogrammetry }\end{array}$ & $\begin{array}{l}\text { 1-degree } \times 1 \text {-degree block } \\
\text { by download }\end{array}$ & $\begin{array}{c}\text { The National Map }{ }^{2} \text { and } \\
\text { GeoPlatform }{ }^{3} 2014 .\end{array}$ \\
\hline 2 arc-second DEM & $\mathrm{AK}$ & $\begin{array}{l}\text { Lidar, ifsar, } \\
\text { photogrammetry }\end{array}$ & $\begin{array}{l}\text { 1-degree } \times 1 \text {-degree block } \\
\text { by download }\end{array}$ & $\begin{array}{c}\text { The National Map }{ }^{2} \text { and } \\
\text { GeoPlatform }{ }^{3} 2014 .\end{array}$ \\
\hline $\begin{array}{l}\text { Elevation-point } \\
\text { query }\end{array}$ & $\begin{array}{l}\text { CONUS, HI, some } \\
\text { U.S. territories, and } \\
\text { AK }\end{array}$ & $\begin{array}{l}\text { 1/3 arc-second DEM, } \\
\text { except } 1 \text { arc-second } \\
\text { DEM in AK }\end{array}$ & Application service & $\begin{array}{l}\text { The National Map } \\
2014 \text {. }\end{array}$ \\
\hline Hillshade & $\begin{array}{l}\text { CONUS, HI, some } \\
\text { U.S. territories, and } \\
\text { AK }\end{array}$ & $\begin{array}{l}\text { 1/3 arc-second DEM, } \\
\text { except } 1 \text { arc- } \\
\text { second DEM in AK }\end{array}$ & Viewing service & $\begin{array}{c}\text { The National Map }{ }^{2} \text { and } \\
\text { GeoPlatform } 2014 \text {. }\end{array}$ \\
\hline
\end{tabular}

${ }^{1}$ All release dates are preliminary.

${ }^{2}$ U.S. Geological Survey, The National Map, (2014b).

${ }^{3}$ Geospatial Platform (2014c, 2014d, 2014e, 2014 f, 2014g, 2014h, 2014i).

${ }^{4}$ The contour interval is dependent on local topographic relief as published on the US Topo map, a georeferenced digital map produced by the U.S. Geological Survey from The National Map data. 

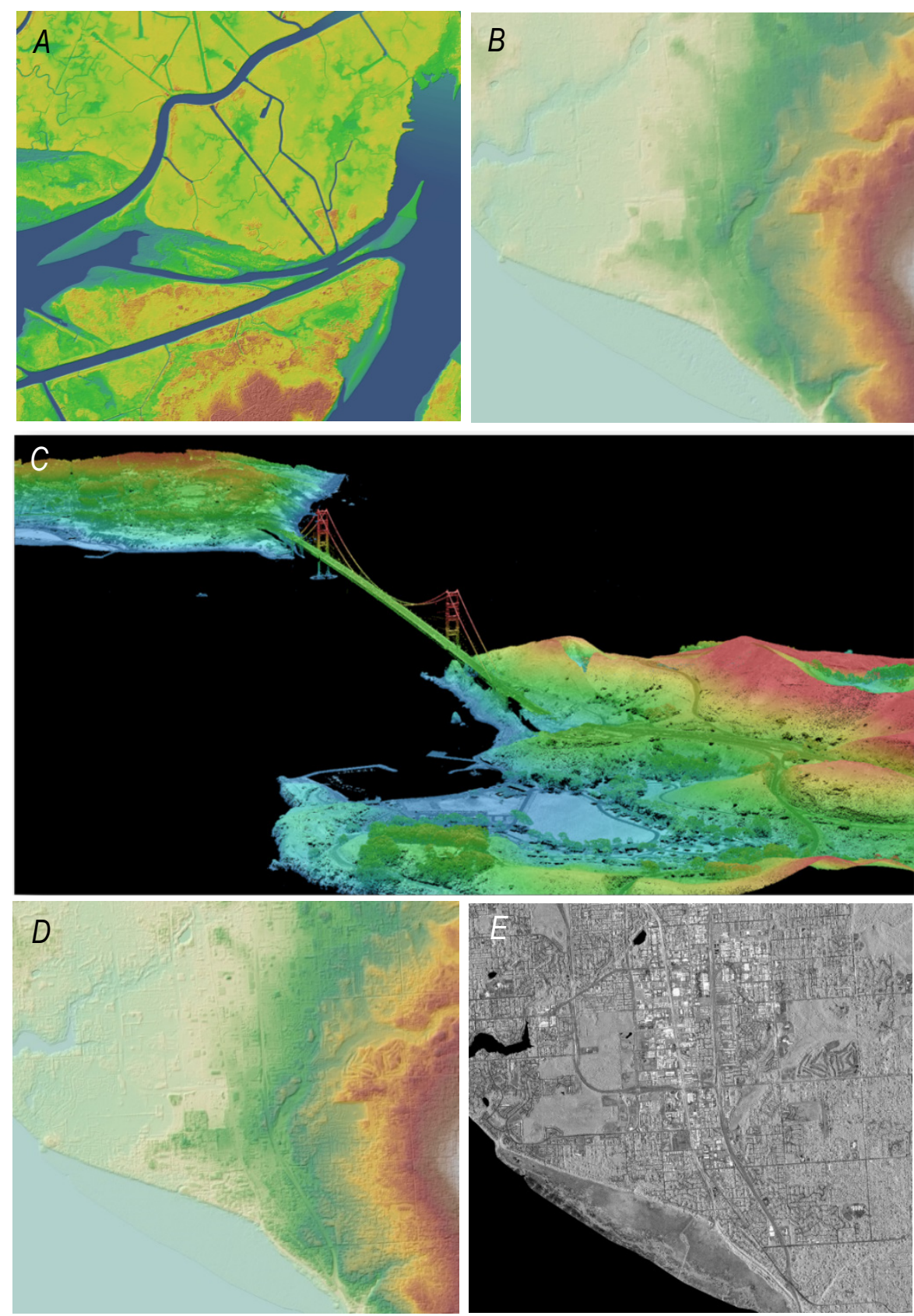

Figure 4. Examples of new products and services available through The National Map. A, 1-meter digital elevation model (DEM); $B, 5$-meter DEM in Alaska; $C$, light detection and ranging point cloud source dataset; $D$, interferometric synthetic aperture radar source digital surface models; and, $E$, orthorectified radar intensity data in Alaska. Images created by J. M. Stoker (U.S. Geological Survey).

The 3DEP Executive Forum, the Civil Applications Committee, and the White House Office of Science and Technology Policy cosponsored a Federal roundtable meeting on September 16, 2014, to explore the status and potential of emerging lidar technologies from the Defense community and National Aeronautics and Space Administration. These systems can collect high-resolution data from aircraft flying higher and faster, which potentially reduces the cost of lidar acquisition. Future commercialization of more efficient technology has the potential to produce new benefits and increase 
the return on investment for future 3DEP acquisitions. One of the action items from the meeting was to establish a working group to identify steps to test the systems and evaluate their ability to address 3DEP requirements. An unclassified forum for building collaborations between Federal Civilian and Defense agencies will be established in FY 2015 to explore the utility of cutting-edge 3D technologies for future use in 3DEP.

\section{Summary}

The 3D Elevation Program (3DEP) initiative is a multi-agency objective, led by USGS to acquire, manage, and distribute enhanced three-dimensional elevation data for the Nation and U.S. territories by 2023. The implementation phase is during 2013-15. This status report covers 2013-2014. The final implementation report will be issued for 2015; and, subsequently, status reports will be issued for the operational accomplishments beginning in 2016. Implementation is defined as that period of time in which support is garnered and funding objectives are met for the program initiative; furthermore, the management structure is being developed, systems are being modernized, and initial production is getting a head start on the 8-year operational objective to collect 3DEP data. The reader is cautioned to understand that the operational phase is defined as the 8-year period in which most of the data are acquired and made available. The country will not have complete coverage of 3DEP quality data until 2023 assuming that sufficient funding is available to complete the program.

The 3DEP initiative is recognized as an aggressive goal, especially when the condition of Federal and State budgets is strained by any reasonable measure. In spite of the overall condition of government budgets, the 3DEP initiative has gained widespread support and had incremental budget success. Emergency funding has supported data collections on the Atlantic Coast and in Colorado. National Geospatial Program funds within the U.S. Geological Survey have been redirected to 3DEP. The Federal Emergency Management Agency and Natural Resources Conservation Service are fully supporting the Broad Area Announcement process for issuing grants and acquiring data through a more formal process. The President's fiscal year 2016 budget request includes modest increases for 3DEP.

The systems that have been developed to support increasing acquisition and processing levels are largely in place. The first 3DEP quality datasets were released to the public in late 2014. In addition, light detection and ranging, interferometric synthetic aperture radar, and digital elevation models acquired before 2014 are all supported within the new infrastructure and available for download. Other Federal agencies and the states are routinely adopting the U.S. Geological Survey data acquisition specifications, which outlines the minimum standard for 3DEP quality data collections. Research is ongoing to expand the suite of products and services, and to increase overall throughput and data management efficiency. Elevation data acquired by 3DEP partnerships will be available through The National Map representing one of the largest and most comprehensive databases publicly available for the United States..

The prospect for a successful operational launch with significant funding increases is good. Since there is much work to be done, the 3DEP Executive Forum and a wide range of professional organizations are actively working to maintain support for the program. Emerging technologies may result in lower acquisition costs in a few short years. Stay current on the latest 3DEP accomplishments by visiting www.nationalmap.gov/3DEP/. 


\section{References Cited}

American Society for Photogrammetry and Remote Sensing, 2012, LASer (LAS) file format exchange activities: Bethesda, Md., American Society for Photogrammetry and Remote Sensing, accessed August 24, 2015, at http://www.asprs.org/Committee-General/LASer-LAS-File-Format-ExchangeActivities.html.

American Society for Photogrammetry and Remote Sensing, 2014, ASPRS positional accuracy standards for digital geospatial data, edition 1, version 1.0: American Society for Photogrammetry and Remote Sensing, Photogrammetric Engineering and Remote Sensing v. 81, no. 3, p. A1-A26. [Also available at http://dx.doi.org/10.14358/PERS.81.3.A1-A26.]

Geospatial Platform, 2014a, USGS lidar point cloud LAS harvest source: Geospatial Platform, U.S. Geological Survey, accessed August 24, 2015, at https://www.geoplatform.gov/node/243/55e6777309ac-459c-8be3-3fb2750ddc9b.

Geospatial Platform, 2014b, USGS NED original product resolution (OPR) downloadable data collection: Geospatial Platform, U.S. Geological Survey, accessed August 24, 2015, at https://www.geoplatform.gov/node/243/a3be5059-5495-4f95-9a14-b03deb9eade0.

Geospatial Platform, 2014c, USGS National Elevation Dataset (NED) 1 meter downloadable data collection: Geospatial Platform, U.S. Geological Survey, accessed August 24, 2015, at https://www.geoplatform.gov/node/243/988723e5-b093-4520-9ea3-cbfea7769bae.

Geospatial Platform, 2014d, National Elevation Dataset (NED) 1/9 arc-second collection: Geospatial Platform, U.S. Geological Survey, accessed August 24, 2015, at https://www.geoplatform.gov/node/243/14fa2d80-b6e6-4cda-a7f3-95d740b716e1.

Geospatial Platform, 2014e, National Elevation Dataset (NED) 1/3 arc-second collection: Geospatial Platform, U.S. Geological Survey, accessed August 24, 2015, at https://www.geoplatform.gov/node/243/3ad2089f-be76-4937-8flb-32b81f2a4024.

Geospatial Platform, 2014f, National Elevation Dataset (NED) 1 arc-second collection (IMG format): Geospatial Platform, U.S. Geological Survey, accessed August 24, 2015, at https://www.geoplatform.gov/node/243/4c7396d3-21c7-4cc2-8c34-e42c4cc50ec3.

Geospatial Platform, 2014g, National Elevation Dataset (NED) Alaska 2 arc-second collection: Geospatial Platform, U.S. Geological Survey, accessed August 24, 2015, at https://www.geoplatform.gov/node/243/ff73f68e-0ee5-48d5-8ec4-d5be0d7f076c.

Geospatial Platform, 2014h, Base map services in The National Map: Geospatial Platform, U.S. Geological Survey, accessed August 24, 2015, at https://www.geoplatform.gov/node/243/2b928697$0 \mathrm{c} 13-4555-887 \mathrm{f}-528 \mathrm{c} 5 \mathrm{e} 290 \mathrm{c} 8 \mathrm{~d}$.

Geospatial Platform, 2014i, USGS NED 1/3 arc-second contours: Geospatial Platform, U.S. Geological Survey, accessed August 24, 2015, at https://www.geoplatform.gov/node/243/29f90010-3c63-4928a0bd-53dffb2a5bea.

Heidemann, H.K., 2014, Lidar base specification (ver. 1.2, November 2014): U.S. Geological Survey Techniques and Methods, book 11, chap. B4, 67 p. with appendixes, accessed August 24, 2015, at http://dx.doi.org/10.3133/tm11B4.

Heidemann, H.K., 2012, Lidar base specification version 1.0: U.S. Geological Survey Techniques and Methods, book 11, chap. B4, 63 p.

National Academy of Public Administration, 2013, FEMA flood mapping-Enhancing coordination to maximize performance: Washington, National Academy of Public Administration, accessed August 24, 2015, at http://www.napawash.org/2013/1568-fema-flood-mapping-enhancing-coordination-tomaximize-performance.html. 
Office of Management and Budget, 2002, Coordination of geographic information and related spatial data activities (revised 2002): Office of Management and Budget Circular A-16, accessed August 24, 2015, at http://www.whitehouse.gov/omb/circulars_a016_rev/.

Snyder, G.I., Sugarbaker, L.J., Jason, A.L., and Maune, D.F., 2014, National requirements for improved elevation data: U.S. Geological Survey Open-File Report 2013-1237, 371 p., accessed August 24, 2015, http://dx.doi.org/10.3133/ofr20131237.

Sugarbaker, L.J., Constance, E.W., Heidemann, H.K., Jason, A.L., Lukas, Vicki, Saghy, D.L., and Stoker, J.M., 2014, The 3D Elevation Program initiative-A call for action: U.S. Geological Survey Circular 1399, 35 p., accessed August 24, 2015, at http://dx.doi.org/10.3133/cir1399.

U.S. Geological Survey, 2013, Budget justifications and performance information-Fiscal year 2014: U.S. Department of the Interior, p. A-3, A-4, B-29, B-30, H-37, J-1, J-19, and J-21, accessed August 24, 2015, at http://www.usgs.gov/budget/2014/greenbook/2014_greenbook.pdf.

U.S. Geological Survey, 2014, Budget justifications and performance information-Fiscal year 2015: U.S. Department of the Interior, A-6, A-10, B-32, B-33, H-36, H-41, and J-21-J-24, accessed August 24, 2015, at http://www.usgs.gov/budget/2015/greenbook/2015_greenbook.pdf.

U.S. Geological Survey, The National Map, 2014a, National Enhanced Elevation Assessment: U.S. Geological Survey, The National Map, accessed August 24, 2015 at http://nationalmap.gov/3DEP/neea.html.

U.S. Geological Survey, The National Map, 2014b, The National Map viewer and download platform: U.S. Geological Survey, The National Map, accessed August 24, 2015 at http://nationalmap.gov/viewer.html.

U.S. Geological Survey, Congressional Briefing Series, 2014, Safer communities, stronger economiesin 3D_July 25, 2014: U.S. Geological Survey, accessed August 24, 2015, at http://www.usgs.gov/solutions/2014_july25.html.

U.S. Geological Survey, The National Map, 2015, 3D Elevation Program (3DEP): U.S. Geological Survey, The National Map, accessed 2014 at http://nationalmap.gov/3dep/BAAReferenceMaterials.html.

White House, The, 2014a, Fact sheet-Taking action to support State, local, and tribal leaders as they prepare communities for the impacts of climate change: The White House, Office of the Press Secretary, accessed August 24, 2015 at https://www.whitehouse.gov/the-press-office/2014/07/16/factsheet-taking-action-support-state-local-and-tribal-leaders-they-pre.

White House, The, 2014b, The President meets with his climate task force: The White House video, 4:11 min, posted July 16, 2014, accessed August 24, 2015, at https://www.whitehouse.gov/photosand-video/video/2014/07/16/president-meets-his-climate-task-force\#. [Also available at https://www.youtube.com/watch?v=98supPr7Lgs.] 
ISSN 2331-1258 (online)

http://dx.doi.org/10.3133/ofr20151161 